\title{
Reproductive Success of Multiparous Female Tanner Crab (Chionoecetes bairdi) Fertilizing Eggs With or Without Recent Access to Males
}

\author{
Joel B. Webb \\ Alaska Department of Fish and Game, \\ PO Box 115526, Juneau, AK 99811-5526, USA \\ Email: joel.webb@alaska.gov
}

Webb, J. B. 2009. Reproductive success of multiparous female Tanner crab (Chionoecetes bairdi) fertilizing eggs with or without recent access to males. J. Northw. Atl. Fish. Sci., 41: 163-172. doi:10.2960/J.v41.m611

\begin{abstract}
Sperm storage in female crabs is assumed to provide resiliency in population reproductive potential for exploited crab stocks with male-only harvest restrictions. However, contrasting results have been reported for the reproductive success of female Tanner crab (Chionoecetes bairdi) relying on stored sperm for fertilization. Ovigerous multiparous female $C$. bairdi were collected and held in the laboratory in the absence of males from hatching to extrusion or collected after hatching and extrusion of a subsequent clutch in situ in Glacier Bay, Alaska. Females were classified into two groups based on extrusion site, LE (laboratory) or FE (field). Mating of multiparous females was important for maintenance of reproductive potential as sperm reserves were likely insufficient for full fertilization of an additional egg clutch from stored sperm in $44 \%$ of LE females. High incidence of fresh grasping marks for FE (97\%) versus LE (4\%) females and significantly higher sperm reserves indicated that most FE females were likely to have recently mated. Mean postextrusion spermathecal load and sperm cell counts increased significantly from 0.21 to $0.44 \mathrm{~g}$ and $2.00 \times 10^{7}$ to $9.35 \times 10^{7}$, respectively, between LE and FE females $(p<0.001)$. Both groups of females extruded clutches of normally developing, viable eggs $(>99 \%)$, with similar fecundity. Characterization of spatiotemporal trends in mating status, sperm reserves and egg production in C. bairdi may be valuable for understanding natural variability in reproduction and possible fishery effects on population reproductive potential.
\end{abstract}

Keywords: Alaska, Chionoecetes bairdi, fecundity, Glacier Bay, reproduction, sperm.

\section{Introduction}

The Tanner crab (Chionoecetes bairdi (Rathbun, 1924) Brachyura: Oregoniidae), is widely distributed in temperate, continental shelf habitats in the northern Pacific Ocean. Tanner crab are targeted by economically valuable trap fisheries in southeast Alaska, the Gulf of Alaska, and eastern Bering Sea (Woodby et al., 2005). Typical of many exploited crustaceans, recruitment and abundance of $C$. bairdi stocks in southeast Alaska and the eastern Bering Sea are highly variable and seemingly lack a strong stock-recruit relationship (Zheng and Kruse, 1998, 2003; Zheng et al., 2006). Variability in recruitment may be due to predation by groundfish, larval transport and survival, or effects of bottom tempera- ture on females brooding eggs (Rosenkranz et al., 2001; Zheng and Kruse, 2006).

In the absence of strong stock-recruit relationships, monitoring of measurable indicators of population productivity has been recommended for exploited marine invertebrates (Smith and Sainte-Marie, 2004) and may be particularly important for detection of fishery effects on population reproductive potential (Kruse, 1993). For brachyuran crabs, two measurable indicators of individual reproductive potential are the amount of sperm stored in the spermathecae and the number of eggs carried by females (Orensanz et al., 1998; Sainte-Marie et al., 2002). A management concern for exploited crustacean stocks is that natural variability in the relative 
abundance of males and females or removals of large males by fisheries with male-only harvest rules may lead to skewed sex ratios. A reduction in male numbers may limit female sperm reserves or egg production and increase the proportion of females in a population fertilizing a clutch with sperm stored from previous matings potentially decreasing population reproductive potential (Smith and Jamieson, 1993; Sainte-Marie et al., 2002; Hines et al., 2003; Carver et al., 2005).

Male C. bairdi typically provide a greater number of sperm in a single copulation than is needed to fertilize a full egg clutch and surplus sperm is stored in paired spermathecae (Adams and Paul, 1983). Female C. bairdi which have completed the terminal molt to reproductive maturity, after which copulation and extrusion of the first egg clutch occurs, are termed primiparous (Paul and Adams, 1984). Multiparous females, carrying a second or later clutch, may produce a clutch from fresh sperm obtained by copulating in hard-shell condition after larval hatching has occurred or by using stored sperm (Adams and Paul, 1983). For multiparous females mating occurs in the spring (March or April) after the completion of larval release and the new clutch of eggs is extruded onto the female's abdomen and incubated for twelve to thirteen months until larval release (Paul and Adams, 1984; Donaldson and Adams, 1989; Swiney, 2008).

Contrasting results in reproductive success have been observed for female $C$. bairdi fertilizing clutches using stored sperm. In one study, most field-collected multiparous females held in the laboratory through single or multiple reproductive cycles without access to males were able to fully fertilize first (97\%) and second (71\%) egg clutches using stored sperm (Paul, 1984). Without mating, females either did not extrude a third clutch or extruded non-dividing oocytes (Paul, 1984). However, in a subsequent study only one in eleven primiparous females which had been mated in the laboratory at the maturity molt produced a viable second clutch with stored sperm. In contrast, ten females allowed to mate both at the maturity molt and after hatching the first egg clutch produced full, viable second clutches with higher fecundity than the one primiparous female that relied on stored sperm for her second clutch (Paul and Paul, 1992).

Mating dynamics, sperm transfer, and egg fertilization (Adams and Paul, 1983; Paul, 1984; Donaldson and Adams, 1989; Paul and Paul, 1992) as well as male competency and mating success (Stevens et al., 1993, 1994; Paul et al., 1995) have been investigated in laboratory and field observations for C. bairdi. Studies describing the reproductive success and condition of female $C$. bairdi in situ have been limited in scope (Stevens et al.,
1996) and the timing of the reproductive cycle, sperm reserves, and fertilization success of female $C$. bairdi from Southeast Alaska have not been investigated.

The purpose of this study was to determine whether fertilization success, fecundity, and sperm reserves differed between multiparous female $C$. bairdi that had released larvae and extruded a subsequent clutch in situ versus multiparous females that had hatched and extruded a subsequent clutch in the laboratory while isolated from males. Further objectives were to describe the timing of larval release, mating, egg extrusion and mating frequency for multiparous female C. bairdi from Glacier Bay, Alaska.

\section{Materials and Methods}

Female Tanner crab $(n=152)$ were collected by shrimp pot baited with chopped herring (Clupeas pallasi), at two sites, Muir Sill and Adams Inlet, in the east arm of Glacier Bay in Southeast Alaska (Fig. 1). Sampling took place at approximately two week intervals on 13 April, 27-28 April, and 13-15 May 2006 (Table 1). A subset of females haphazardly selected from field collections were maintained onboard in totes lined with damp burlap for one to two days and then transported by air to Juneau, AK where they were held in 700 litre Living Stream ${ }^{\mathrm{TM}}$ aquaria on a flow-through seawater system at ambient temperatures (mean $\pm \mathrm{SE}$ ) of $6.0 \pm 0.1^{\circ} \mathrm{C}$ through the study period. For all females transported to the laboratory biological data including carapace width, egg development stage (eyed vs. uneyed), presence of fresh grasping marks, and shell condition were recorded for each female within $48 \mathrm{~h}$ of arrival. Grasping marks or areas of lighter coloration on the dorsal surface of the basi-ischium and merus of the first through third pereiopods are due to abrasion of the exocuticle by the chelae of males as females are grasped during the mating period (Paul, 1984). Shell condition, which is an assessment of color and wear on the exoskeleton, was used as an approximate indicator of time since the last molt, and crab were classified as newshell (2-12 months post-molt), old shell (12-24 months post-molt), or very old shell (24+ months post-molt) as wear on the exoskeleton and epibiont load increased (Jadamec et al., 1999). All females with the exception of one female collected on 11 April which was excluded from the study were classified as very old shell and were likely two years or more postmolt. Females retained for laboratory observations were individually marked with plastic Floy ${ }^{\mathrm{TM}}$ tags attached to the third left pereiopod using a plastic tie. Groups of crab from each sampling date were held communally in aquaria until dissection. At the time of collection, 


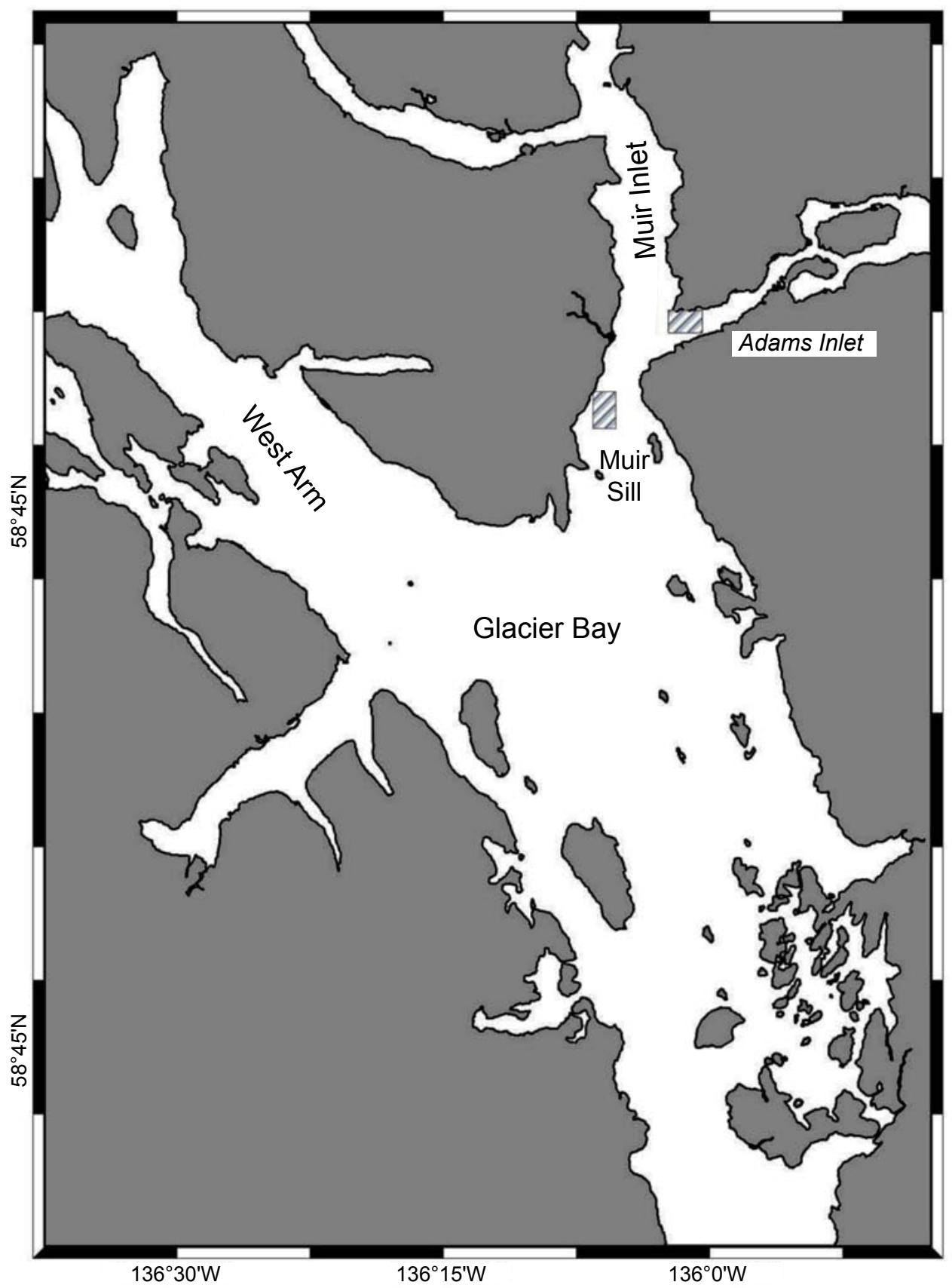

Fig. 1. Hatched boxes indicate locations in Muir Sill and Adams Inlet, Glacier Bay, Alaska, where multiparous female Chionoecetes bairdi were collected by shrimp pot between 13 April and 15 May 2006.

females were categorized into two groups by egg clutch status for comparison of reproductive potential. Females which had likely completed larval release, mated if males were present, and extruded a new clutch of eggs likely fertilized with fresh sperm were termed the field extrusion (FE; $n=21)$ group; these females carried uneyed eggs in early stages of development. Females brooding eyed eggs extruded the previous year were held in the laboratory without access to males through hatching and subsequent extrusion, thereby relying on stored sperm for fertilization of subsequent clutches, and were termed the laboratory extrusion (LE; $n=10$ ) group.

\section{Mating and sperm reserves}

For assessment of sperm reserves, females were dissected and spermathecae were removed two to three weeks post-extrusion for LE and FE females when egg 
TABLE 1. Date, area of collection, number, and proportion by egg clutch development stage of multiparous female C. bairdi from Glacier Bay, Alaska collected in the field and used in laboratory studies in 2006. Reductions in sample size were due to mortality during transport or subsampling. The proportion of females with fresh (new) grasping marks was determined only for females transported to the laboratory.

\begin{tabular}{|c|c|c|c|c|c|c|c|}
\hline \multicolumn{8}{|c|}{ Field Collections } \\
\hline Sampling Date & Area & $n$ & Eyed Eggs & Barren & Uneyed Eggs & Unknown & \\
\hline 13 April & Muir Sill & 19 & 1.00 & 0.00 & 0.00 & 0.00 & \\
\hline 27 April & Muir Sill & 7 & 0.86 & 0.00 & 0.00 & 0.14 & \\
\hline 28 April & Adams Inlet & 32 & 0.13 & 0.06 & 0.81 & 0.00 & \\
\hline 13 May & Muir Sill & 15 & 0.07 & 0.00 & 0.93 & 0.00 & \\
\hline 15 May & Adams Inlet & 80 & 0.06 & 0.04 & 0.90 & 0.00 & \\
\hline \multicolumn{8}{|c|}{ Retained for Laboratory Study } \\
\hline Sampling Date & Area & $n$ & Eyed Eggs & Barren & Uneyed Eggs & Unknown & Grasping Marks \\
\hline 13 April & Muir Sill & 19 & 1.00 & 0.00 & 0.00 & 0.00 & 0.00 \\
\hline 27 April & Muir Sill & 6 & 1.00 & 0.00 & 0.00 & 0.00 & 0.17 \\
\hline 28 April & Adams Inlet & 27 & 0.15 & 0.07 & 0.78 & 0.00 & 0.76 \\
\hline 15 May & Adams Inlet & 15 & 0.00 & 0.00 & 1.00 & 0.00 & 0.93 \\
\hline
\end{tabular}

development reached the $>256$ cell cleavage stage. The left spermatheca was preserved in $10 \%$ formalin buffered with saltwater. At least seven days after preservation the left spermatheca was removed from formalin, the wall of the spermathecae was removed and the spermathecal load (SL) or weight of the spermathecal contents was measured to the nearest $0.01 \mathrm{~g}$ on a Mettler-Toledo Model PL-202-S microbalance. Estimated sperm cell counts were determined by homogenization and dilution of spermathecal contents followed by visual counts of sperm cells using replicate hemacytometers. Two $\mathrm{ml}$ of water were added to each sample which was then homogenized for eight minutes in a Potter-Vilhelm tissue grinder with a Wheaton overhead stirrer. After homogenization, de-ionized water was added to the sample to equal $1 \mathrm{ml}$ for each $0.01 \mathrm{~g}$ of spermathecal content. Cell counts were conducted on two replicate hemacytometers of $0.1 \mathrm{ml}$ volume at $400 \times$ magnification on an Olympus DP-20 compound microscope. Ten frames representing $0.10 \%(0.40 \mathrm{ml})$ of hemacytometer volume were counted. Sperm cells were easily identified by bright acrosomes and defined cell walls. If the four replicate counts (two from each hemacytometer) differed by more than $15 \%$, counts were repeated. Estimates of sperm cell counts were calculated as the mean of the four counts multiplied by the dilution factor. To produce a normalized estimate for comparison of sperm reserves among females, estimated sperm cell counts were divided by the spermathecal load for each female.

\section{Fertilization success and fecundity}

To determine the fertilization rate, the abdomen with the clutch attached was separated from the female when the spermathecae were removed. A subsample of $\sim 50$ to 100 eggs was removed from the base of each pleopod and each egg was classified as viable or non-developing based on structure (size, orientation, and number of dividing cells) and color. For measurement of fecundity, the eggs were examined for development (400-600 per female) counted and combined in a pre-weighed drying pan. To separate the egg clutch from the abdomen each of the eight pleopods was clipped at the base of the inner ramus. Eggs were gently stripped from each pleopod using forceps and eggs from all pleopods were combined for each crab in a pre-weighed drying pan. The egg subsample and clutch were then dried to constant weight in a $60^{\circ} \mathrm{C}$ oven for $>48 \mathrm{~h}$ and measured to the nearest $0.1 \mathrm{mg}$ on a Mettler AE163 analytical microbalance.

\section{Timing of the reproductive cycle}

Females collected with eyed eggs at Muir Sill on 13 April were monitored for hatching and extrusion of a subsequent clutch in the laboratory. Visual examination of the clutch at the time of capture and microscopic examination in the laboratory (18 April) indicated that the eyed clutches of females were at the pre-hatching stage (Moriyasu and Lanteigne, 1998). To detect larval release a filter constructed from $500 \mu \mathrm{m}$ Nitex $^{\mathrm{TM}}$ mesh 
was placed on the aquarium outflow on 18 April. To monitor the progression of hatching and extrusion of a subsequent clutch, the egg clutch of each female was examined and visually classified by the ratio of egg cases to unhatched eggs (none, egg cases visible, $\sim$ 1:1 ratio of egg cases to unhatched eggs) at three day intervals from 20 April until a clutch of new, uneyed eggs was extruded. The duration of hatching was estimated as the number of days from the first observation of empty egg cases to the date on which a freshly extruded egg clutch was observed for each individual. Following extrusion approximately 30 eggs were removed from the center of the ventral surface of the egg mass at two to three day intervals and examined on a Wild-Heerbrung dissecting microscope at $32 \times$ magnification to determine the proportion of eggs undergoing cleavage and the cleavage stage by the number of observed blastomeres.

\section{Statistical analyses}

Levene's test for homogeneity of variance and the Shapiro-Wilk $W$ test for normality confirmed that data met assumptions for parametric analysis. Significant differences in spermathecal load, estimated sperm cell counts, and sperm cells per gram of spermathecal load, and fecundity between groups of females were determined using $t$-tests. Relationships between spermathecal load and sperm cell counts between FE and LE females were investigated by ANCOVA of slopes and intercepts (Zar, 1999). Outliers in the spermathecal load versus sperm cell count relationship were identified by Cook's distance. All statistical analyses were conducted in JMP 6.02 (SAS Institute, Cary, NC).

\section{Results}

\section{Grasping marks and sperm reserves}

The proportion of females with fresh grasping marks and the proportion of females bearing clutches of uneyed versus eyed eggs increased by sampling date from early (13 April) to late in the study period (15 May). The incidence of fresh grasping marks also varied among groups of females increasing from $4 \%$ for females with eyed eggs or no clutch (barren) to $97 \%$ for females with uneyed eggs (Table 1).

Sperm reserves varied between the FE and LE females (Table 2). Spermathecal load (mean \pm SD) differed significantly $(t=4.68$; df $=28 ; p<0.001)$ from $0.21 \pm 0.13 \mathrm{~g}$ among LE females $(n=9)$ to $0.44 \pm 0.12 \mathrm{~g}$ among FE $(n=21)$ females. Estimated sperm cell counts $($ mean $\pm \mathrm{SD})$ also differed significantly $(t=5.85 ; \mathrm{df}=29$; $p<0.001)$ from $2.00 \times 10^{7} \pm 2.38 \times 10^{7}$ among LE females $(n=10)$ to $9.35 \times 10^{7} \pm 3.59 \times 10^{7}$ among FE females $(n=21)$. Estimated sperm cell counts per 0.1 gram spermathecal load (mean \pm SD) increased significantly $(t=4.17 ; \mathrm{df}=28 ; p<0.001)$ from $8.70 \times 10^{6} \pm 7.84 \times 10^{6}$ for LE females to $2.16 \times 10^{8} \pm 7.68 \times 10^{7}$ for FE females. Linear regression indicated that sperm counts increased significantly $\left(F=8.99 ; \mathrm{df}=20 ; r^{2}=0.32 ; p<0.001\right)$ with increasing spermathecal load for FE females but not LE $\left(F=2.63 ; \mathrm{df}=8 ; r^{2}=0.27 ; p<0.14\right)$ females. However, excluding one female identified as an outlier with high spermathecal load $(0.44 \mathrm{~g})$ and low sperm cell count $\left(4.87 \times 10^{6}\right)$; sperm cell counts also increased significantly with spermathecal load for LE females $(F=43.6$,

TABLE 2. Spermathecal load, number of sperm cells, and sperm cells per $0.10 \mathrm{~g}$ of spermathecal load for multiparous female Tanner crab from Glacier Bay, Alaska held without access to males, extruding a clutch of eggs in the lab, and relying on sperm reserves (LE) for egg fertilization or collected after hatching, mating, and extrusion of a subsequent clutch in the field (FE). Probability values are for $t$-tests of differences between LE and FE females.

\begin{tabular}{lrrrccc}
\hline \hline Group & $n$ & Mean & SD & Min & Max & $P$ \\
\hline \multicolumn{7}{c}{ Spermathecal Load (g) } \\
LE & 9 & 0.21 & 0.13 & 0.06 & 0.44 & $<0.001$ \\
FE & 21 & 0.44 & 0.12 & 0.24 & 0.73 & \\
\multicolumn{7}{c}{ Number of Sperm Cells } \\
LE & 10 & $2.00 \times 10^{7}$ & $2.38 \times 10^{7}$ & $6.50 \times 10^{5}$ & $6.77 \times 10^{7}$ & $<0.001$ \\
FE & 21 & $9.35 \times 10^{7}$ & $3.59 \times 10^{7}$ & $3.77 \times 10^{7}$ & $1.73 \times 10^{8}$ & \\
\multicolumn{7}{c}{ Number of Sperm Cells per 0.1 g Spermathecal Load } \\
LE & 9 & $8.70 \times 10^{7}$ & $7.84 \times 10^{7}$ & $8.13 \times 10^{6}$ & $2.24 \times 10^{8}$ & $<0.001$ \\
FE & 21 & $2.16 \times 10^{8}$ & $7.68 \times 10^{7}$ & $9.98 \times 10^{7}$ & $4.23 \times 10^{8}$ & \\
\hline \multicolumn{7}{c}{}
\end{tabular}




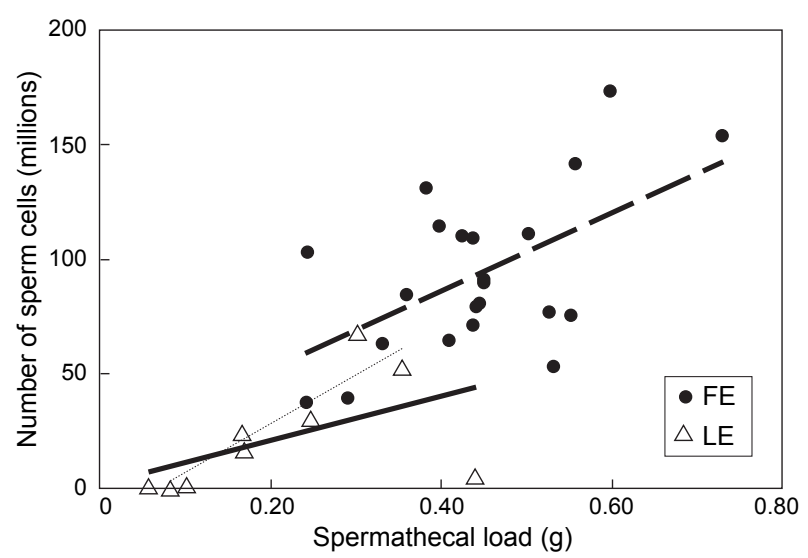

Fig. 2. Number of sperm cells and spermathecal load for multiparous female Tanner crab from Glacier Bay, Alaska, hatching and extruding a subsequent clutch in the field (FE; $n=21$ ) presumably after mating (circles), or hatching and extruding a subsequent clutch fertilized with stored sperm in the laboratory (LE; $n=9$ ) without mating (triangles). Linear regression indicated that sperm counts increased significantly $\left(F=8.99, \mathrm{df}=20, r^{2}=0.32, p<0.001\right)$ with increasing spermathecal load for FE females (broken line) but did not $\left(F=2.63\right.$, df $\left.=8, r^{2}=0.27, p<0.14\right)$ for LE (solid line) females including the female with high $(0.44 \mathrm{~g})$ spermathecal load and low sperm cell count $\left(4.87 \times 10^{6}\right)$ but did increase significantly $(F=43.6$, $\left.\mathrm{df}=7, r^{2}=0.88, p<0.001\right)$ excluding this female (dotted line). Slopes and intercepts were homogenous between the LE and FE groups. See Table 2 for summary of sperm reserves by group.

$\mathrm{df}=7, r^{2}=0.88, p<0.001$; Fig. 2). Slopes and intercepts of regression lines of spermathecal load versus sperm cell counts were homogenous between the $\mathrm{FE}$ and LE groups both including (slopes: $t=0.77$; $\mathrm{df}=27, p>0.05$; intercepts: $t=1.47$; $\mathrm{df}=27 ; p>0.05$ ) and excluding (slopes: $t=0.49$; $\mathrm{df}=26 ; p>0.05$; intercepts: $t=1.47$; $\mathrm{df}=26 ; p>0.05)$ the female with high spermathecal load and low sperm cell count (Fig. 2).

\section{Fertilization success and fecundity}

The proportion (mean, range) of normally cleaving eggs at the $>32$ cell stage, assumed to be fertilized, was similar between the $\operatorname{LE}(0.998,0.986-1.00)$ and FE $(0.997,0.992-1.00)$ groups. Fecundity (mean \pm SD) was also similar $(t=1.58 ; \mathrm{df}=18 ; p=0.06)$ between FE females (143000 $\pm 51700 ; n=21)$ and LE females $(114600 \pm 41600 ; n=9)$. Fecundity comparisons were independent of female size as carapace width (mean $\pm \mathrm{SD})$ was not significantly different $(t=0.64$; $\mathrm{df}=20 ; p=0.26)$ between the FE $(91.0 \pm 8.7 \mathrm{~mm}$; $n=21)$ and LE (89.1 $\pm 6.6 \mathrm{~mm} ; n=9)$ groups (Fig. 3).

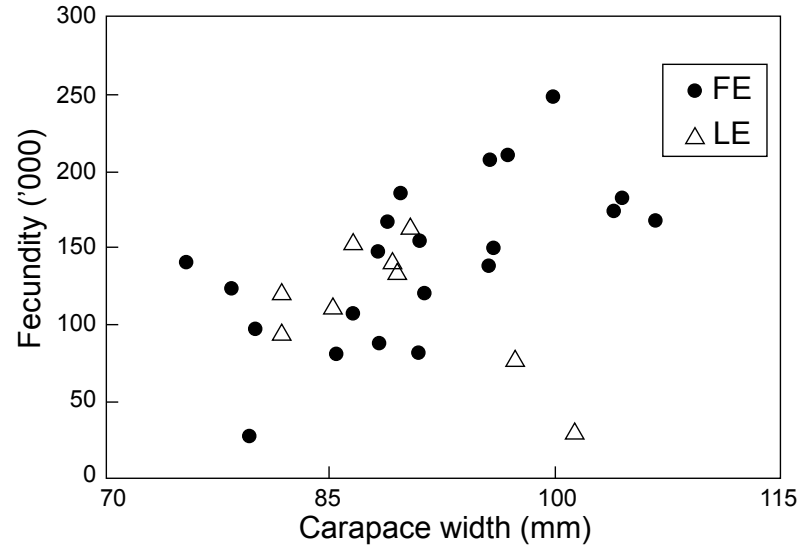

Fig. 3. Fecundity and carapace width of multiparous female Tanner crab from Glacier Bay, Alaska, hatching and extruding a subsequent clutch in the field (FE; $n=21$ ) after mating (circles), or hatching and extruding a subsequent clutch fertilized with stored sperm in the laboratory (LE; $n=9$ ) without mating (triangles).

The fecundities of LE females were clustered into two groups with two females with relatively low fecundity and seven with fecundities similar to those of FE group females (Fig. 3). Linear regression of sperm cell counts with residuals of the fecundity/size relationship indicated that fecundity did not vary significantly with sperm cell counts for either LE $\left(F=0.21\right.$; df $=8, r^{2}=0.03$; $p=0.66)$ or $\mathrm{FE}\left(F=0.69, \mathrm{df}=20, r^{2}=0.04, p=0.41\right)$ females (Fig. 4).

\section{Timing of the reproductive cycle}

Hatching was first observed in the laboratory on 20 April and concluded on 17 May. Individual duration of hatching based on visual assessment of the clutch $(n=19)$ ranged from 3 to $15 \mathrm{~d}$ with a mean of $9 \mathrm{~d}$, but resolution was limited by the three day sampling interval. Sixteen of nineteen females monitored for hatching and extrusion in the laboratory extruded a new clutch within three days of completing larval release. The ovaries of two of the three females that did not extrude clutches were white and did not contain oocytes suggesting that they might be senescent.

Field assessment of egg condition (eyed or uneyed) suggested that the timing of larval release and extrusion in situ was similar to that observed in the laboratory. Eighty-six percent of the females collected at Muir Sill on 27 April had clutches of eyed eggs, while $13 \%$ of the 28 April Adams Inlet females had clutches of eyed eggs (Table 1). Approximately two weeks later on 13 May and 15 May, $92 \%$ and $93 \%$, respectively, of females were observed with uneyed embryos at both Muir Sill and Adams Inlet (Table 1). 


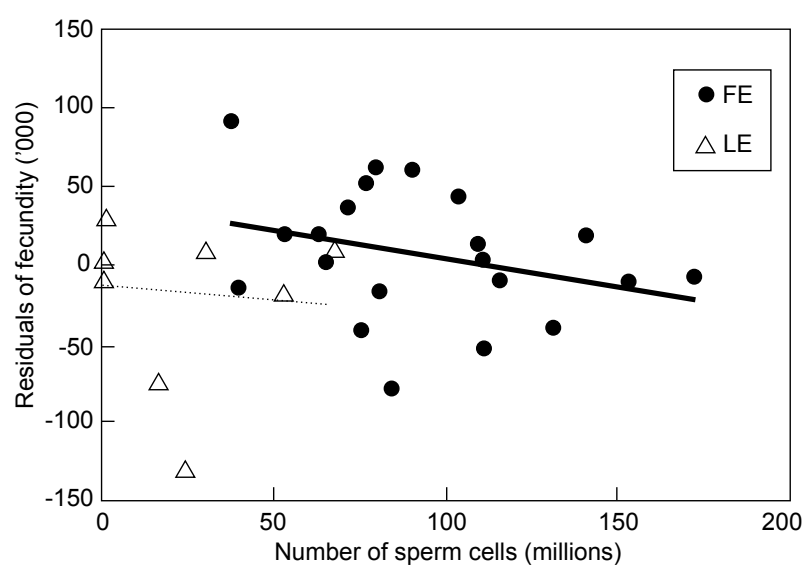

Fig. 4. Residuals of the fecundity-size relationship and number of sperm cells for multiparous female Tanner crab from Glacier Bay, Alaska, hatching and extruding a subsequent clutch in the field (FE) with access to males (circles), or hatching and extruding a subsequent clutch fertilized with stored sperm in the laboratory (LE) without mating (triangles). Linear regression indicated that residuals of fecundity-size did not vary significantly with sperm cell counts for either LE (dotted line; $F=0.05$, df $=8, r^{2}=0.01, p<0.82$ ) or FE (solid line; $F=1.87$, df $=20, r^{2}=0.09, p<0.19$ ) females.

\section{Discussion}

Multiparous female $C$. bairdi collected from Glacier Bay had sufficient stored sperm to produce a subsequent clutch of viable eggs. Egg fertilization rates were similar between multiparous female Tanner crab fertilizing clutches using stored sperm while isolated from males in the laboratory and females hatching, presumably mating, and extruding a subsequent clutch in the field. These results confirm those of Paul (1984) in which most fieldcollected multiparous female $C$. bairdi successfully fertilized at least two clutches without mating, but contrast with those of Paul and Paul (1992) in which ten of eleven females relying on sperm stored from a single copulation at the molt-to-maturity failed to produce a subsequent clutch of viable eggs. Variability in the number of reproductive cycles completed, the amount and characteristics of sperm transferred by males (Sainte-Marie and Lovrich, 1994; Rondeau and Sainte-Marie, 2001), or variability in sperm viability may account for differences in reproductive success and sperm reserves observed among these studies.

Similar to this study, Paul (1984) investigated egg viability, sperm reserves, and fecundity of multiparous females which were ovigerous at capture. Female sperm reserves in this study and in Paul (1984) were the prod- uct of in situ reproductive dynamics, while in Paul and Paul (1992) mating occurred under laboratory conditions. In this study, assuming that the number of sperm cells was similar between paired spermathecae (SainteMarie and Lovrich, 1994), the mean sperm cell count for females that fertilized a single clutch from stored sperm was $4.00 \times 10^{7}$ (Table 2), which was an order of magnitude higher than the value of $1.6 \times 10^{6}$ observed by Paul (1984). Based on assessment of the condition of the exoskeleton, all females in this study were classified as very old shell (Jadamec et al., 1999) and were likely brooding their third or greater clutch. Thus, sperm reserves were likely the result of reproductive dynamics and processes occurring in situ over several annual reproductive cycles. Since the shell condition of females studied by Paul (1984) was not specified it is unclear whether sperm reserves for these females were acquired over two or more reproductive cycles which limits potential comparisons between these studies. Another factor limiting comparison is the use by Paul (1984) of a constant relationship of sperm cells per unit volume of spermathecal content determined in a previous study for sperm cell counts of multiparous females. The number of sperm cells per unit weight of spermathecal content observed among LE females in this study ranged over two orders of magnitude (Table 2) indicating that the density of sperm cells is likely to vary considerably among fieldcollected multiparous female C. bairdi. Mean sperm cell counts per spermatheca of multiparous females in this study (Table 2) were also greater than those observed for primiparous $C$. bairdi in field collections and laboratory studies. Primiparous C. bairdi from the eastern Bering Sea had a mean of $5.539 \times 10^{6}$ sperm cells in a single spermatheca (Gravel and Pengilly, 2007) and sperm cell counts ranged from $4.0 \times 10^{4}$ to $4.9 \times 10^{6}$ in primiparous C. bairdi mated only at the molt to maturity in the laboratory (Adams and Paul, 1983).

Male Tanner crab are capable of transferring sperm in excess of that required for fertilization of a single egg clutch during a single mating (Adams and Paul, 1983) so annual mating may allow females to accrue increasing levels of sperm reserves, but this may be moderated or negated if sperm viability decreases with increasing storage time or mating does not occur annually or varies with interannual variability in the amount of sperm transferred by males (Sainte-Marie et al., 2002). In this study, mean sperm cell counts per unit weight of spermathecal load were much higher in FE females than LE. If decreased sperm viability were detectable it might be expected that the intercept of the regression would be lower for LE than FE females in Fig. 2 which was not observed. An estimated 70 sperm cells were expended to 
fertilize each oocyte for primiparous C. opilio from eastern Canada (Sainte-Marie and Lovrich, 1994). If similar sperm cell:oocyte ratios were necessary for fertilization in multiparous $C$. bairdi and subsequent clutch sizes were similar among LE females, four of nine LE females in this study would have insufficient sperm reserves to produce a another fully fertilized egg clutch using stored sperm.

If sperm stored from a single mating is insufficient to maximize lifetime reproductive potential for female C. bairdi (Paul and Paul, 1992) then mating of multiparous females may be necessary to maintain population reproductive potential. In this study an increasing proportion of multiparous female C. bairdi collected biweekly in Glacier Bay from mid-April to mid-May had obtained fresh grasping marks and significant increases in spermathecal load and sperm cell counts were observed between females captured prior to hatching and after extrusion in situ. While grasping marks may not be a consistently reliable indicator of mating success (Duluc et al., 2005), fresh grasping marks are a proximate indicator of male presence during the annual mating period (Somerton, MS 1981; Paul, 1984). Differences in the incidence of grasping marks and significant increases of sperm reserves of $\mathrm{FE}$ females relative to LE females suggests that mating occurred for most multiparous females in the study area during the study period.

Male:female sex ratio, multiparous female mating frequency, and sperm reserves may be higher in the area where females were collected for this study relative to other areas of Glacier Bay and greater southeast Alaska. The east arm of Glacier Bay where females were collected for this study is within Glacier Bay National Park and has been closed to commercial fishing since 1999 (64 Fed. Reg. 202:56455-56464), though commercial harvest does occur in the adjacent central bay. Annual stock assessment surveys have not been conducted in this area but a comprehensive pot sampling in 2002 and limited sampling during the study period indicated that the relative abundance of mature males was high in this area (Nielsen et al., 2007; J. Nielsen, pers. comm., University of Alaska Fairbanks, Juneau, Alaska 99801). In other areas of Southeast Alaska, model estimates of mature male $C$. bairdi commercial fishery exploitation rates range spatiotemporally from $\leq 30 \%$ to $\geq 80 \%$ (Zheng et $a l ., 2006)$. If fishery removals result in skewed sex ratios, lower female sperm reserves may result (Sainte-Marie et al., 2002; Carver et al., 2005).

Previous studies suggested that fecundity was lower for multiparous female C. bairdi that fertilized egg clutches with stored sperm relative to females that had mated prior to extrusion (Paul, 1984). No significant differences in fecundity independent of female size were observed between LE and FE females in this study. The fecundity of LE females was dichotomous with one group having similar fecundity to FE females $(n=7)$ while two other had lower fecundity relative to FE females of similar size (Fig. 3). Factors associated with the decreased fecundity of these two females remain unclear as large numbers of sloughed or dropped eggs not observed on the bottom of aquaria during monitoring of extrusion, sperm cell counts were high relative to other LE females, and neither female was missing limbs.

Field and laboratory data indicate that the timing and the duration of larval release, mating, and extrusion are similar for C. bairdi in southeast Alaska and in the western Gulf of Alaska near Kodiak Island (Stevens, 2003; Swiney, 2008). In laboratory observations of $C$. bairdi females collected near Kodiak Island, hatch timing was interannually variable occurring in April or May, the duration of larval release was $9.4 \mathrm{~d}$, and larvae were relesased over a period of approximately one month from late April to late May (Stevens et al., 1994; Stevens, 2003; Swiney, 2008). These results are similar to the laboratory observations of an approximately nine day larval release period for individual females and April to May hatching and extrusion period observed for female C. bairdi from Glacier Bay. Field observations of females bearing clutches of eyed eggs in mid and lateApril and most females bearing clutches of uneyed eggs by mid-May suggested that the timing of larval release in situ in Glacier Bay was similar to that observed in the laboratory.

Multiparous female C. baridi which had either extruded in the field with access to males or fertilized eggs in the laboratory with stored sperm both produced and retained clutches with similar numbers of viable eggs. Assuming that multiparous C. bairdi have a sperm to egg ratio similar to primiparous C. opilio (Sainte-Marie and Lovrich, 1994), and given that only $56 \%$ of the LE females that fertilized one clutch would have sufficient sperm reserves to fertilize a subsequent clutch of similar size, multiparous mating is likely important for maintaining population reproductive potential. High incidence of grasping marks and increased sperm reserves indicated that most females collected after extrusion in situ had likely mated during the study period. Differences in sperm cell counts per unit weight spermathecal load differed between females in this study suggesting that further investigation (e.g. controlled studies) of the relationship of sperm cells to unit weight spermathecal load between primiparous and multiparous females of known mating history could provide insight into trends of sperm 
viability with storage time in C. bairdi. Finally, since this study characterized sperm reserves, fecundity, and mating frequency of multiparous females in an area closed to fishing, these results may be suitable for evaluation of possible spatiotemporal differences in egg production and sperm reserves in multiparous female $C$. bairdi in areas with high male exploitation rates or naturally skewed sex ratios.

\section{Acknowledgements}

Special thanks to Ms. Julie Nielsen and Dr. S. James Taggart, of the United States Geological Survey, Glacier Bay Field Station and Mr. Jim DelaBreure, captain of the "R/V Alaska Gyre", who collected females and collected field data on female clutch condition for this study in the course of a study on movement of $C$. bairdi in Glacier Bay. I would also like to thank Drs. Ginny Eckert and Sherry Tamone of the University of Alaska Southeast and Jie Zheng of the Alaska Department of Fish and Game for logistical support and encouragement. Thanks to members of the Eckert Lab at the University of Alaska Fairbanks for comments on earlier drafts of this manuscript. The manuscript was also improved by comments of two anonymous reviewers. This is contribution PP-249 of the Alaska Department of Fish and Game, Commercial Fisheries Division, Juneau, Alaska.

\section{References}

ADAMS, A. E., and A. J. PAUL. 1983. Male parent size, sperm storage, and egg production in the crab Chionoecetes bairdi (Decapoda: Majidae). Int. J. Invertebr. Reprod., 6: 181-187.

CARVER, A. M., T. G. WOLCOTT, D. L. WOLCOTT, and A. H. HINES. 2005. Unnatural selection: Effects of a malefocused size-selective fishery on reproductive potential of a blue crab population. J. Exp. Mar. Biol. Ecol., 319: 29-41. doi:10.1016/j.jembe.2004.06.013

DONALDSON, W. E., and A. E. ADAMS. 1989. Ethogram of behavior with emphasis on mating for the Tanner crab Chionoecetes bairdi Rathbun. J. Crust. Biol., 9: 37-53. doi: $10.2307 / 1548445$

DUL UC, C., B. SAINTE-MARIE, and J. C. BRÊTHES. 2005. Value of indicators for assessing recent mating in brachyuran crabs. J. Mar. Biol. Ass. U.K., 85: 129-135. doi:10.1017/S0025315405010945h

GRAVEL, K. A., and PENGILLY, D. 2007. Investigations on reproductive potential of snow and Tanner crab females from the eastern Bering Sea in 2005. Fishery Data Series No. 07-23. Alaska Department of Fish and Game, Juneau, Alaska, 99801. 43 p. http://www.sf.adfg.state.ak.us/FedAidPDFs/fds07-23.pdf

HINES, A. H., P. R. JIVOFF, P. J. BUSHMANN, J. VAN MONTFRANS, S. A. REED, D. L. WOLCOTT, and T.
G. WOLCOTT. 2003. Evidence for sperm limitation in the blue crab, Callinectes sapidus. Bull. Mar. Sci., 72: 287-310.

JADAMEC, L. S., W. E. DONALDSON, and P. CULLENBURG. 1999. Biological Field Techniques for Chionoecetes Crabs. University of Alaska Sea Grant College Program, AK-SG-99-02. University of Alaska Fairbanks, 80 p. http://seagrant.uaf.edu/bookstore/pubs/ AK-SG-99-02.html

KRUSE, G. H. 1993. Biological perspectives on crab management in Alaska. In: Proceedings of the International Symposium on Management Strategies for Exploited Fish Populations. G. Kruse, D. M. Eggers, R. J. Marasco, C. Puatzke, and T. J. Quinn II (eds.). Alaska Sea Grant College Program Report No. 93-02, University of Alaska Fairbanks, p. 355-384.

MORIYASU, M., and C. LANTEIGNE. 1998. Embryo development and reproductive cycle in the snow crab, Chionoecetes opilio (Crustacea: Majidae), in the southern Gulf of St. Lawrence, Canada. Can. J. Zool., 76: 2040-2048. doi:10.1139/cjz-76-11-2040

NIELSEN J. K., S. J. TAGGART, T. C. SHIRLEY, and J. MONDRAGON. 2007. Spatial distribution of juvenile and adult female Tanner crabs (Chionoecetes bairdi) in a glacial fjord ecosystem: implications for recruitments processes. ICES J. Mar. Sci., 64: 1772-1784. doi:10.1093/ icesjms/fsm 158

ORENSANZ, J. M., J. ARMSTRONG, D. ARMSTRONG, and R. HILBORN. 1998. Crustacean resources are vulnerable to serial depletion - the multifaceted decline of crab and shrimp fisheries in the Greater Gulf of Alaska. Rev. Fish. Biol. Fish., 8: 117-176. doi:10.1023/A:1008891412756

PAUL, A. J. 1984. Mating frequency and viability of stored sperm in the Tanner crab Chionoecetes bairdi (Decapoda: Majidae). J. Crust. Biol., 4: 375-381. doi: $10.2307 / 1548037$

PAUL, A. J., and A. E. ADAMS. 1984. Breeding and fertile period for female Chionoecetes bairdi (Decapoda: Majidae). J. Crust. Biol., 4: 589-594. doi:10.2307/1548073

PAUL, A. J., and J. M. PAUL. 1992. Second clutch viability of Chionoecetes bairdi Rathbun (Decapoda: Majidae) inseminated only at the maturity molt. J. Crust. Biol., 12: 438-441. doi:10.2307/1549037

PAUL, A. J., J. M. PAUL, and W. E. DONALDSON. 1995. Shell condition and breeding success in Tanner crabs. $J$. Crust. Biol., 15: 476-480. doi:10.2307/1548769

RONDEAU, A., and B. SAINTE-MARIE. 2001. Variable mate-guarding time and sperm allocation by male snow crabs (Chionoecetes opilio) in response to sexual competition, and their impact on the mating success of females. Biol. Bull., 201: 204-217. doi:10.2307/1543335

ROSENKRANZ, G. E., A. V. TYLER, and G. H. KRUSE. 2001. Effects of water temperature and wind on year-class success of Tanner crabs in Bristol Bay, Alaska. Fish. Oceanogr., 10: 1-12. doi:10.1046/j.1365-2419.2001.00153.x

SAINTE-MARIE, B., and G. A. LOVRICH. 1994. Delivery and storage of sperm at first mating of female Chionoecetes opilio (Brachyura: Majidae) in relation to size and morphometric maturity of male parent. J. Crust. Biol., 14: 
508-521. doi:10.2307/1548997

SAINTE-MARIE, B., J. M. SÉVIGNY, and M. CARPENTIER. 2002. Interannual variability of sperm reserves and fecundity of the snow crab (Chionoecetes opilio) in relation to sex ratio. Can. J. Fish. Aquat. Sci., 59: 1932-1940. doi:10.1139/f02-162

SMITH, B. D., and G. S. JAMIESON. 1991. Possible consequences of intensive fishing for males on the mating opportunities of Dungeness crabs. Trans. Am. Fish. Soc., 120: 650-653. doi:10.1577/15488659(1991) $120<0650: \mathrm{NPCOIF}>2.3 . \mathrm{CO} ; 2$

SMITH, S. J., and B. SAINTE-MARIE. 2004. Biological reference points for invertebrate fisheries: introduction. Can J. Fish. Aquat. Sci., 61: 1303-1306. doi:10.1139/f04-135

SOMERTON, D. A. MS 1981. Life history and population dynamics of two species of Tanner crab, Chionoecetes bairdi and $C$. opilio in the eastern Bering Sea with implications for the management of the commercial harvest. Unpublished doctoral dissertation, University of Washington, Seattle.

STEVENS, B. G., W. E. DONALDSON, J. A. HAAGA, and J. E. MUNK. 1993. Morphometry and maturity of paired Tanner crabs, Chionoecetes bairdi, from shallow- and deepwater environments. Can. J. Fish. Aquat. Sci., 50: 1504-1516.

STEVENS, B. G., J. A. HAAGA, and W. E, DONALDSON. 1994. Aggregative mating of Tanner crabs, Chionoecetes bairdi. Can. J. Fish. Aquat. Sci., 51: 1273-1280. doi:10.1139/f94-127

STEVENS, B. G., J. A. HAAGA, W. E. DONALDSON, and S. A. PAYNE. 1996. Reproductive conditions of prespawning multiparous female Tanner crabs (Chionoecetes bairdi) from Chiniak and Womens Bays, Kodiak Island, Alaska. In: High Latitude Crabs: Biology, Management, and Economics. Alaska Sea Grant College Report No. 96-02, University of Alaska Fairbanks, p. 343-348.

STEVENS, B.G. 2003. Timing of aggregation and larval release by Tanner crabs, Chionoecetes bairdi, in relation to tidal current patterns. Fish. Res., 65: 201-216. doi:10.1016/j. fishres.2003.09.015

SWINEY, K. M. 2008. Egg extrusion, embryo development, timing and duration of eclosion, and incubation period of primiparous and multiparous Tanner crabs (Chionoecetes bairdi). J. Crust. Biol., 28: 334-341. doi:10.1651/02780372(2008)028[0334:EEEDTA]2.0.CO;2

WOODBY, D., D. CARLILE, S. SIDDEEK, F. FUNK, J. H. CLARK, and L. HULBERT. 2005. Commercial Fisheries of Alaska. Special Publication No. 05-09. Alaska Department of Fish and Game, Juneau, Alaska 99801

ZAR, J. H. 1999. Biostatistics. $4^{\text {th }}$ ed. Prentice-Hall Inc., New Jersey, USA, $653 \mathrm{p}$.

ZHENG, J., and G. H. KRUSE. 1998. Stock-recruitment relationships for Bristol Bay Tanner crab. Alaska Fish. Res. Bull., 5: 116-130.

2003. Stock-recruitment relationships for three major Alaskan crab stocks. Fish. Res., 65: 103-121. doi:10.1016/j.fishres.2003.09.010

2006. Recruitment variation of eastern Bering Sea crabs: Climate forcing or top-down effects? Prog. Oceanogr., 68: 184-204. doi:10.1016/j.pocean.2006.02.002

ZHENG, J., J. M. RUMBLE, and G. H. BISHOP. 2006. Estimating Southeast Alaska Tanner crab abundance using pot survey and commercial catch data. Alaska Fish. Res. Bull., 12: 196-211. 